\title{
PENGARUH PENAMBAHAN TEPUNG Spirulina platensis DALAM PAKAN TERHADAP PERTUMBUHAN DAN EFISIENSI PAKAN IKAN MAS KOKI (Carassius auratus)
}

\section{THE SUPPLEMENTATION EFFECT OF DIFFERENT CONCENTRATION OF Spirulina platensis FLOUR ON ARTIFICIAL FEED AGAINST THE GROWTH AND FEED EFFICIENCY OF GOLDFISH}

\author{
Nuraini Nazhiroh $^{a}$, Mulyana ${ }^{b}$, Fia Sri Mumpuni ${ }^{b}$ \\ ${ }^{a}$ Mahasiswa S1 Program Studi Akuakultur Fakultas Pertanian Uiversitas Djuanda Bogor \\ ${ }^{b}$ Staf Pengajar Program Studi Akuakultur Fakultas Peranian Universitas Djuanda Bogor \\ J1. Tol Ciawi 1, Pos 35 Bogor 16720 \\ E-mail : aini.andalusia@gmail.com
}

\begin{abstract}
The research is aimed to know the supplementation effect of different concentration of Spirulina platensis fluor on artificial feed against the growth and feed efficiency of goldfish. The experimental research was carried out on September 2018 until April 2019 at The Fisheries Laboratory, Djuanda University, Bogor. The experimental research used completely randomized design with 4 treatments and each 3 replications. The treatments are K (Control, without supplementation of Spirulina platensis fluor), A (30 g of Spirulina platensis fluor +1 $\mathrm{kg}$ of artificial feed), B (60 g of Spirulina platensis fluor $+1 \mathrm{~kg}$ of artificial feed), and C (90 $\mathrm{g}$ of Spirulina platensis fluor $+1 \mathrm{~kg}$ of artificial feed). The total length growth, the weight growth, feed efficiency, and water quality (temperature, $\mathrm{pH}$, dissolved oxygen, and $\mathrm{NH}_{3}$ ) had been evaluated. The results of research showed there was a significantly different between treatments for the growth and feed efficiency $(\mathrm{P}<0.05)$. The best results were obtained in treatment B with an average total length growth of $2.19 \mathrm{~cm}$, average weight growth of $1.51 \mathrm{~g}$, and average feed efficiency of $30.26 \%$. Water quality during the research are temperaure of 25.6-27.5 ${ }^{\circ}$, $\mathrm{pH}$ of 7.2-8.3, DO of 6.2-7.1 mg/L, and $\mathrm{NH}_{3}$ of $0.01-0.30 \mathrm{mg} / \mathrm{L}$.
\end{abstract}

Key words : Goldfish, Spirulina platensis, growth, feed efficiency

\begin{abstract}
ABSTRAK
Penelitian ini memiliki tujuan mengetahui pengaruh penambahan tepung Spirulina platensis yang berbeda dalam pakan buatan terhadap pertumbuhan dan efisiensi pakan ikan mas koki. Penelitian percobaan dilaksanakan pada bulan September 2018 - April 2019, bertempat di Laboratorium Perikanan, Fakultas Pertanian, Universitas Djuanda Bogor. Penelitian percobaan ini menggunakan Rancangan Acak Lengkap (RAL), dengan 4 perlakuan dan 3 kali ulangan. Sebagai perlakuan adalah K (tanpa penambahan Spirulina platensis dalam pakan, sebagai Kontrol), A (tepung Spirulina platensis $30 \mathrm{~g}+1 \mathrm{~kg}$ pakan), B (tepung Spirulina platensis $60 \mathrm{~g}+1 \mathrm{~kg}$ pakan), C (tepung Spirulina platensis $90 \mathrm{~g}+1 \mathrm{~kg}$ pakan). Parameter yang diteliti dalam penelitian percobaan ini meliputi pertumbuhan panjang total ikan, pertumbuhan berat ikan, efisiensi pakan ikan, dan kualitas air (suhu, pH, DO, dan NH3). Hasil penelitian menunjukkan bahwa penambahan tepung Spirulina platensis kedalam pakan ikan berpengaruh nyata terhadap pertumbuhan dan efisiensi pakan $(\mathrm{P}<0,05)$. Hasil terbaik didapatkan pada perlakuan B dengan rataan pertumbuhan panjang total $2,19 \mathrm{~cm}$, rataan
\end{abstract}


pertumbuhan berat $1,51 \mathrm{~g}$, dan rataan efisiensi pakan 30,26\%. Kualitas air selama penelitian yaitu, suhu 25,6-27, $5^{\circ} \mathrm{C}, \mathrm{pH} 7,2-8,3$, DO 6,2-7,1 mg/L, dan NH3 00,1-0,30 mg/L.

Kata Kunci: Mas Koki, Spirulina platensis, Pertumbuhan, Efisiensi Pakan

Nuraini, Mulyana, Fia Sri Mumpuni. 2019. Pengaruh Penambahan Tepung Spirulina platensis Dalam Pakan Terhadap Pertumbuhan Dan Efisiensi Pakan Ikan Mas Koki (Carassius auratus). Jurnal Mina Sains 5(1): 50 - 57.

\section{PENDAHULUAN}

Ikan mas koki (Carassius auratus) ialah ikan hias yang memiliki wujud tubuh, dan warna yang beragam dengan warna yang berbeda-beda sepeerti merah kuning, hijau, hitam sampai keperak-perakan (Fazil et al. 2017). Mas koki merupakan ikan hias berasal dari Cina.oleh sebab itu ikan hias mas koki ini menjadikan kemungkinan usaha besar dan berpotensial buat dibudidayakan di Indonesia, lantaran penggemar dalam negeri besar dan tidak kalah dengan peminat luar negeri (Marbun et al. 2015).

Dalam budidaya ikan, pakan salah satu unsur penting dalam menunjang pertumbuhan dan kelangsungan hidup ikan. Menurut Mulyadi et al. (2011) menyatakan bahwa, pertumbuhan ikan itu dapat didukung oleh tersedianya pakan yang cukup serta didukung oleh pemberian tebar yang optimal, dimana pakan dikonsumsi kian tinggi dibanding kebutuhan ikan untuk pertumbuhan. Pakan yang terdapat pada tubuh ikan terproses ditubuh sertaa unsurr-unsur nutrisinya akan menyerap serta termanfaatkan untuk menyusun jaringan-jaringan sampai terjadi pertumbuhan. Pertumbuhan yang terdapat ditubuh ikan lebih mempengaruhi dari jenis dan kualitass pakan yang diberikan. Pakan berkeadaan yang baik menghasilkan pertumbuhan serta efisiensi pakan, yang tinggi. Secara ekonomis, efisiensi pakan tinggi akan mempengaruhi biaya pakan sehingga berpengaruh pada biaya produksi (Isnawati et al. 2015).

Spirulina platensis adalah mikro-alga hijau-biru yang banyak dibudidayakan secara komersil. Spirulina platensis merupakan mikroalga dengan protein tinggi dibanding sumber lain sehingga berpotensi dikembangkan sebagai pakan alami (Nur 2014). Kandungan protein pada Spirulina platensis kering mencapai $65 \%$ dan kandungan vitaminnya tinggi. Beberapa penelitian memperlihatkan bahwa Spirulina platensis dapat mencegah kanker pada manusia dan hewan. Studi in vitro menunjukkan polisakarida unik dari aktivitas enzim sel inti Spirulina platensis menambah dan memperbaiki sintesis DNA (Ali dan Saleh 2012).

Kandungan protein Spirulina platensis berat kering adalah $60-70 \%$ (Koru 2012). Protein Spirulina platensis ialah senyawa-senyawa kompleks yang terdapat banyaknya asam amino essensial, metionin $(1,3-2,75 \%)$, sistin $(0,5-0,7 \%)$, triptofan $(1-1,95 \%)$, dan lisin $(2,6-$ $4,63 \%)$. Kadar asam amino yang banyak bagus untuk kesehatan, dikenal ialah salah satu molekul pembuat protein. Senyawa senyawa lainnya yang berada dilemak adalah asam palmitat $(44,6-54,1 \%)$, asam oleat $(1-15,5 \%)$, dan asam linoleat $(10,8$ - 30,7\%). Spirulina platensis mengandung kolesterol sekitar 32,5 mg/100 g dan mengandung karbohidrat $17-25 \%$, karotein $0,43 \%$, klorofil $0,8 \%$, serta kandungan air $3-6 \%$ (Christwardana \& Hadiyanto 2013).

\section{Tujuan}

Tujuan dari penelitian percobaan ini agar mengetahui efek penambahan tepung Spirulinaa pada pakan buatan terhadap pertumbuhan dan efisiensi pakan ikan mas koki (Carassius auratus) dengan dosis berbeda. 


\section{Hipotesis}

Hipotesis dari penelitian ini ialah meningkatnya pertumbuhan dan efisiensi pakan pada ikan mas koki (Carassius auratus) dengan tepung Spirulina terdapat dipakan ikan.

\section{BAHAN DAN METODE Waktu dan Tempat}

Penelitian ini dilaksanakan bulan September 2018 sampai April 2019 di Laboratorium Perikanan Fakultas Pertanian Universitas Djuanda Bogor.

\section{Alat dan Bahan}

Alat-alat yang dipergunakan untuk penelitian tentang pertumbuhan ialah penggaris, timbangan digital, serokan, kamera dan alat tulis. Peralatan pengukuran kualitas air yaitu Do, $\mathrm{pH}$ meter, dan thermometer. Wadah percobaan adalah akuarium $30 \times 30 \times 30 \mathrm{~cm}$ sebanyak 12 wadah pemeliharaan.

Bahan-bahan yang digunakan penelitian ini ialah 120 ekor ikan mas koki, yang berukuran $\pm 2,5 \mathrm{~cm}$ dengan berat $\pm 0,5$, serta berumur 2 bulan, tepung Spirulina platensis, pakan Hi-Pro-Vit.

\section{Rancangan Penelitian}

Rancangan penelitian percbaan ini menggunakan RAL (Rancangan Acak Lengkap) bersama 4 perlakuan serta 3 kali ulangan. Adapun perlakuan penelitian ini ialah :

Perlakuan K: Tanpa Spirulina platensis

(Kontrol)

Perlakuan A: Penambahan $1 \mathrm{~kg}$ pakan +30 $\mathrm{g}$ tepung Spirulina platensis

Perlakuan B: Penambahan $1 \mathrm{~kg}$ pakan +60

$\mathrm{g}$ tepung Spirulina platensis

Perlakuan C: Penambahan $1 \mathrm{~kg}$ pakan +90 $\mathrm{g}$ tepung Spirulina platensis

\section{Prosedur Penelitian \\ Persiapan Wadah}

Wadah pemeliharaan ikan mas koki menggunakan akuarium ukuran $100 \mathrm{~cm} \times$
$40 \mathrm{~cm} \times 40 \mathrm{~cm}$ sebanyak 1 unit dan wadah untuk penelitian sebanyak 12 unit akuarium bervolume $30 \mathrm{~cm} \times 30 \mathrm{~cm} \times 30$ $\mathrm{cm}$. Sebelum dipakai, sebelumnya akuarium dibersihkan terlebih dahulu menggunakan sabun, setelah bersih akuarium pemeliharaan diisi air sebanyak tinggi $20 \mathrm{~cm}$ untuk setiap wadah percobaan.

\section{Persiapan Ikan Uji}

Ikan yang akan terpakai penelitian ini ialah ikan mas koki panjangnya $\pm 2,5$ $\mathrm{cm}$ dengan berat $\pm 0,5 \mathrm{~g}$ dengan umur 2 bulan. Selama dipelihara ikan uji diberikan perlakuan sama seperti pemberian pakan pelet merk HI-PRO-VIT kadar protein $29,84 \%$ dan kadar air 10,63\%.Ikan diadaptasikan pada media budidaya. Setelah selesai diadaptasikan ikan dipuasakan 24 jam bertujuan untuk membersihkan kotoran di tubuh ikan. Kemudian ikan ditimbang serta dihitung panjangnya lalu dimasukkan kedalam akuarium Setelah itu, ikan ditebar 10 ekor/akuarium atau media uji.

\section{Persiapan Pakan}

Jenis pakan yanng dipakai penelitian yaitu pakan buatan jenis pelet yang dicampur dengan Spirulina platensis dan dijadikan pakan berbentuk pasta. Pakan kontrol sendiri ialah tidak mengandung Spirulina platensis, Dosis yang digunakan $30 \mathrm{~g}$ tepung Spirulina platensis $+1 \mathrm{~kg}$ pakan, untuk $60 \mathrm{~g}$ tepung Spirulina platensis $+1 \mathrm{~kg}$ pakan, selanjutnya untuk $90 \mathrm{~g}$ tepung Spirulina platensis $+1 \mathrm{~kg}$ pakan. pemberian pakan pasta yang mengandung tepung Spirulina platensis sebanyak 2 kali sehari pukul 08:00 dan 16:00 WIB. Banyaknya jumlah pakan yang diberikan sebanyak 5 gram.

\section{Pemeliharaan}

Pemeliharaan ikan selama 28 hari dilakukan pembersihan air secara rutin dengan cara penyifonan setiap hari. Volume air yang disifon $10 \%$ dari wadah pemeliharaan. Kualitas pendukung yang 
diteliti adalah pH, suhu, dan Do. Pengukuran kualitas air dilakukan 2 kali sehari.

\section{Parameter Uji}

\section{Pertumbuhan Panjang Ikan}

Pertumbuhan panjang ikan yang akan dilakukan penelitian ini pada hari ke-0, ke-9, ke-18 dan ke-28 pengukuran meliputi panjnangnya total ikan dari ujung mulut sampai ujung ekor ikan. Pengukuran panjang ikan menggunakan prnggaris berskala sentimeter. Perhitungan panjang dihitung dengan rumus Effendie (1979), yaitu :

$$
\mathbf{L}_{\mathbf{m}}=\mathbf{L}_{\mathbf{t}}-\mathbf{L}_{\mathbf{0}}
$$

Keterangan :

$\mathrm{L}_{\mathrm{m}}=$ Pertumbuhan panjang mutlak ikan (cm)

$\mathrm{L}_{\mathrm{t}}=$ Panjang ikan pada waktu ke-t $(\mathrm{cm})$

$\mathrm{L}_{0}=$ Panjang ikan pada waktu ke-0 $(\mathrm{cm})$

\section{Pertumbuhan Berat Ikan}

Pertumbuhan berat ikan menggunakan timbangan digital. Pertambahan berat dihitung dengan rumus Effendie (1979), yaitu:

Keterangan :

$$
\mathbf{W}_{\mathbf{m}}=\mathbf{W}_{\mathbf{t}}-\mathbf{W}_{\mathbf{0}}
$$

$\mathrm{Wm}=$ Pertambahan bobot mutlak ikan $(\mathrm{g})$

$\mathrm{W}_{\mathrm{t}}=$ Bobot ikan pada waktu ke-t $(\mathrm{g})$

$\mathrm{W}_{0}=$ Bobot ikan pada waktu ke-0 $(\mathrm{g})$

\section{Efisiensi pakan}

Penghitungan Efisiensi pakan dengan rumus Zonneveld et al.(1991) sebagai berikut:

$$
E P=\frac{(\mathbf{W t}+\mathbf{D})-\mathbf{W o}}{\mathbf{F}} \times 100 \%
$$

Keterangan :

$\mathrm{EP}=$ Efisiensi pakan $(\%)$

$\mathrm{W}_{\mathrm{t}}=$ Bobot ikan uji pada akhir penelitian (g)

$\mathrm{W}_{\mathrm{o}}=$ Bobot ikan uji pada awal penelitian (g)

$\mathrm{D}=$ Bobot total ikan yang mati $(\mathrm{g})$

$\mathrm{F}=$ Jumlah total pakan yang diberikan (g)

\section{Kualitas Air}

Pengukuran kualitas air meliputi suhu, pH, DO dan amonia. Alat ukur yag digunakan yaitu $\mathrm{pH}$ meter, Do meter, Termometer dan Spektrofotometer. Pengukuran suhu dan $\mathrm{pH}$ diukur setiap hari selama pemeliharaan.

\section{Analisis Data}

Data dianalisis menggunakan analisa ragam (ANOVA) untuk mengetahui pengaruh perlakuan terhadap parameter. Apabila berpengaruh nyata, melihat perbedaan perlakuan akan diuji menggunakan uji Duncan. Setelah itu data disajikan dalam bentuk tabel

\section{HASIL DAN PEMBAHASAN Pertumbuhan Ikan Mas Koki (Carassius auratus)}

Hasil yang didapat selama penelitian terdapatnya perubahan pertumbuhan panjang dan berat ikan mas koki dapat dilihat (Gambar 1 dan 2). Pertumbuhan panjang dan berat ikan mas koki terbaik didapatkan perlakuan $\mathrm{B}$ yaitu rata-rata sebesar 2,19 cm dan 1,91 g. Hasil analisis ragam (ANOVA) menunjukkan bahwa penambahan tepung Spirulina platensis terhadap pakan ikan hias mas koki berbeda nyata $(\mathrm{P}<0,05)$ terhadap pertumbuhan panjang dan bobot ikan mas koki yang dipelihara selama 28 hari. Peningkatan pertumbuhan terbaik pada perlakuan B diduga karena kadar protein yang terdapat pada pakan $\mathrm{B}$ dengan kandungan tepung Spirulina platensis mencukupi kebutuhan nutrisi ikan mas koki dan mampu menyerap nutrisi dengan baik sehingga tidak ada protein pada pakan yang terbuang. Protein dibutuhkan untuk pembentukan enzim, hormon dan protein penyusun plasma sebagai sumber energi, sehingga diduga ikan memanfaatkan energi untuk metabolisme sehingga terjadi pertumbuhan. Ikan mas koki adalah ikan omnivora pemakan daging dan tumbuhan, sehingga bisa memakan segala makanan untuk kebutuhan hidup dan pertumbuhan. Kebutuhan protein ikan omnivora yaitu 25- 
30\%. Menurut Lochmann \& Phillip (1994) estimasi protein untuk ikan mas koki yaitu kurang lebih 29\%. Menurut Hasan (2012) bahwa kadar protein $37,91 \%$ merupakan level optimum yang menghasilkan pertumbuhan. Pakan yang diberikan sesuai protein pada kebutuhan ikan menghasilkan penyerapan nutrisi yang bauus, untuk laju pertumbuhan. Pada perlakuan Kontrol dan A menghasilkan pertumbuhan yang rendah terhadap pertumbuhan ikan mas koki. Hal ini dikarenakan kandungan protein pada pakan kontrol dan A mengandung protein lebih sedikit dari perlakuan B. Pada perlakuan kontrol dan A mungkin diduga kurangnya protein, sehingga nutrisi dalam tubuh ikan mas koki untuk pertumbuhan tidak cukup, akibatnya nutrisi yang masuk hanya akan menghasilkan energi tapi kurang untuk membentuk sel jaringan. Pada perlakuan C dengan dosis Spirulina platensis lebih besar dari perlakuan kontrol dan A menghasilkan pertumbuhan yang tidak berbeda nyata. Penurunan pertumbuhan pada kadaran protein ini diduga akibat kelebihan protein yang terdapat dalam ikan mas koki. Menurut Furuichi (1988) kelebihan protein pada pakan justru akan memperhambat pertumbuhan dikarenakan penimbunan protein pada saluran pencernaan sehingga penyerapan nutrisi terdapat ditubuh ikan tidak terhidrolisir dengan baik. Saluran pencernaan pada benih ikan biasanya belum terbentuk dengan sempurna sehingga enzim-enzim untuk menghidrolisis protein pada alat pencernaan ikan masih sedikit. Hal ini diperkuat oleh Putra (2010) yaitu enzimenzim yang ada pada alat pencernaan ikan digunakan untuk membantu menghidrolisir nutrien pada pakan seperti memecah protein, karbohidrat, dan lemak menjadikan molekul-molekul mudah atau sederhana, nantinya akan mempermudah proses penyerapan nutrisi terdapat didalam tubuh ikan untuk pertumbuhan. Sehingga hail ini diduga turunnya pertumbuhan ikan pada perlakuan $\mathrm{C}$ diakibatkan enzim yang belum terbentuk sempurna pada pencernaan tubuh ikan sangat sulit memproses nutrisi pakan yang berlebih. Kelebihan protein pada ikan juga tidak baik untuk pertumbuhan diduga kelebihan protein dapat memicu metabolisme untuk proses penyerapan protein pada tubuh ikan tinggi sehingga diperlukan energi yang berlebih. Hal ini meyebabkan protein yang seharusnya tersimpan pada tubuh ikan akan lebih banyak dipakai untuk energi dan diekskresikan protein menjadi ammonia (Yudiarto et al. 2012).

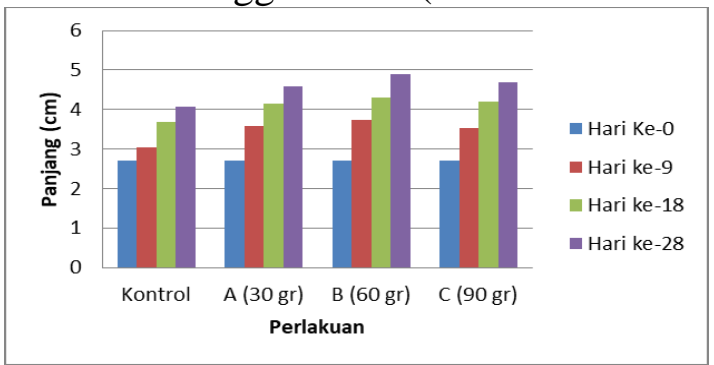

Gambar 1 Grafik Pertumbuhan Panjang Mas Koki (Carassius auratus)

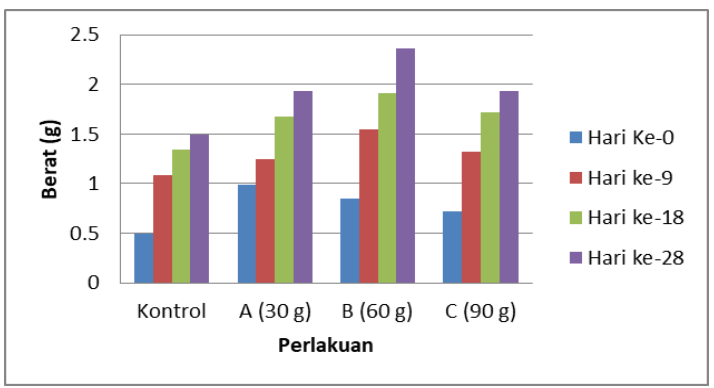

Gambar 2 Grafik Pertumbuhan Berat Mas Koki (Carassius auratus) 


\section{Efisiensi Pakan}

Hasil efisiensi selama penelitian yaitu rata-rata $30.26 \%$ (Tabel 1). Hasil analisis ragam (ANOVA) menunjukkan bahwa penambahan tepung Spirulina platensis terhadap pakan ikan hias mas koki berbeda nyata $(\mathrm{P}<0,05)$ terhadap efisiensi pakan ikan mas koki pada perlakuan B yang dipelihara selama 28 hari. Hasil efisiensi terbaik yang dihasilkan pada perlakuan yaitu rata-rata $30.26 \%$ (Tabel 1). Hal ini membuktikan bahwa pada perlakuan B yang mengandung tepung Spirulina platensis memberikan efisiensi dalam pakan dengan dosis $60 \mathrm{~g}$ tepung Spirulina terdapat pada pakan yang hanya diberi pakan pelet saja atau kontrol. Efisiensi pakan menunjukkan seberapa besar pakan termanfaatkan oleh ikan untuk pertumbuhan. Menurut Christwardana et al. (2013) Spirulina sp. berkandungan protein tinggi sekitar 55-70\%. Hal ini diduga penambahan protein pada tepung Spirulina platensis memberikan kualitas pakan yang terbaik sehingga protein terdapat dipakan dimanfaatkan ikan untuk pertumbuhan ikan mas koki sehingga menghasilkan efisiensi pakan yang tinggi.
Efisiensi menurun pada perlakuan $\mathrm{C}$ hal ini diduga kualitas pakan kurang baik dikarenakan diduga kelebihan protein sehingga nutrisi yang masuk tidak terserap dengan baik dikarenakan enzim yang terbentuk pada alat pencernaan ikan untuk memproses pakan serta menyerap nutrisi belum sempurna, sehingga pemanfaatan energi pada pakan untuk metabolisme, pergerakan dan pertumbuhan ikan menurun. Penurunan pada perlakuan A dan kontrol diduga disebabkan kurangnya protein sehingga nutrisi yang dibuthkan terserap pada tubuh ikan tidak terpenuhi. Hal ini diperkuat oleh Isnawati et al. (2015) secara fisiologis pakan akan terpengaruh kepada pertumbuhan dan perkembangan ikan, inti menghasilkan energi, pergerakan dan reproduksi ikan. Pakan yang dimakan ikan akan terproses kedalma tubuh dan nutrisinya akan diserap serta dimanfaatkan untuk membangun jaringan hingga terjadi efisiensi pakan dan pertumbuhan. Menurut Iskandar dan Elrifadah (2015) semakin besar nilai efisiensi pakaan semakin baik pula tingkat pemanfaatan pakan ikan untuk pertumbuhannya.

Tabel 1 Efisiensi Pakan

\begin{tabular}{c|cccc}
\hline \multirow{2}{*}{ Ulangan } & \multicolumn{4}{|c}{ Perlakuan } \\
\cline { 2 - 5 } & Kontrol & $\mathbf{A}$ & $\mathbf{B}$ & $\mathbf{C}$ \\
\hline $\mathbf{1}$ & 13.80 & 14.40 & 26.60 & 19.40 \\
$\mathbf{2}$ & 21.60 & 19.40 & 30.20 & 27.40 \\
$\mathbf{3}$ & 24.20 & 22.20 & 34.00 & 25.80 \\
\hline Rata-rata & $\pm 19.86^{\mathrm{a}}$ & $\pm 18.66^{\mathrm{a}}$ & $\pm 30.26^{\mathrm{b}}$ & $\pm 24.20^{\mathrm{a}}$ \\
\hline
\end{tabular}

Kualitas Air kelangsungan hidup ikan mas koki, yaitu

Selama penelitian dilaksanan kualitas air teramati adalah suhu, $\mathrm{pH}, \mathrm{DO}$, dan ammonia $\left(\mathrm{NH}_{3}\right)$ dapat dilihat pada (Tabel 2). Kualitas air adalah salah satu factor pendukung yang dapat memberikan pertumbuhan dan kehidupan pada ikan. Suhu, oksigen terlarut, dan $\mathrm{pH}$ dapat berpengaruh terhadap laju metabolisme tubuh di mana dapat meningkatkan aktivitas metabolisme dan dapat meningkatkan nafsunya makan ikan (Zonneveld et al. 1991). Hasil kualitas air ikan selama penelitian masih tergolong normal untuk

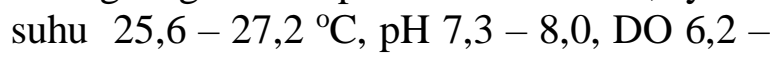
7,0 mg/L, ammonia $0,01-0,30 \mathrm{mg} / \mathrm{L}$. Hal ini ditegaskan oleh Boyd (2015) nilai $\mathrm{pH}$ yang cocok untuk kegiatan budidaya yaitu $\mathrm{pH}$ 6,8-8,5 dan DO lebih dari $5 \mathrm{mg} / \mathrm{L}$. Menurut Muarif (2016) suhu 22-30 ${ }^{\circ} \mathrm{C}$ menempati pada kisaran nilai yang bagus dipakai budidaya perikanan. Linne et al. (2015) ikan yang terus menerus terekspos $\mathrm{NH}_{3}$ pada kosentrasi lebih dari $0,5 \mathrm{mg} / \mathrm{L}$ dapat menurunkan pertumbuhan dan semakin rentan terhadap penyakit. Ammonia dalam penelitian masih dibilang optimal karena penanganan mutu air supaya baik 
dengan seringnya wadah dibersihkan serta feses yang dalam air.

disifon dan tidak adanya sisa pakan atau

Tabel 2 Kualitas Air

\begin{tabular}{c|cccc}
\hline \multirow{2}{*}{ Wadah } & \multicolumn{4}{|c}{ Parameter } \\
\cline { 2 - 5 } & Suhu $\left({ }^{\mathbf{0}} \mathbf{C}\right)$ & $\mathbf{p H}$ & $\mathbf{D O}(\mathbf{m g} / \mathbf{L})$ & $\mathbf{N H}_{\mathbf{3}}(\mathbf{m g} / \mathbf{L})$ \\
\hline Kontrol & $25,6-27,2$ & $7,2-8.2$ & $6,2-7,1$ & $0,01-0,10$ \\
A & $25,7-27,4$ & $7,3-8,0$ & $6,6-7,1$ & $0,02-0,20$ \\
B & $25,6-27,5$ & $7,3-8,3$ & $6,2-7,0$ & $0,02-0,20$ \\
C & $25,6-27,2$ & $7,6-7,9$ & $6,9-7,1$ & $0,10-0,30$ \\
\hline
\end{tabular}

\section{KESIMPULAN DAN SARAN}

Kesimpulan

Penambahan tepung Spirulina platensis berpengaruh nyata terhadap pertumbuhan panjang, pertumbuhan berat dan efisiensi pakan $(\mathrm{P}<0,05)$. Hasil terbaik diperoleh pada perlakuan $\mathrm{B}$ dengan rataan pertumbuhan panjang total $2,19 \mathrm{~cm}$, rataan pertumbuhan berat $1,51 \mathrm{~g}$, dan rataan efisiensi pakan 30,26\%. Kualitas air selama penelitian yaitu, suhu $25,6-27,5^{\circ} \mathrm{C}$, pH 7,2-8,3, DO 6,2-7,1mg/,L, dan $\mathrm{NH}_{3}$ $00,1-0,30 \mathrm{mg} / \mathrm{L}$.

\section{Saran}

Untuk meningkatkan pertumbuhan ikan mas koki, pakan dapat dicampur dengan $60 \mathrm{~g}$ tepung Spirulina platensis +1 kg pakan.

\section{DAFTAR PUSTAKA}

Ali SK, Saleh AM. 2012. Spirulina - an overview. International Journal of Pharmacy and Pharmaceutical Sciences 4(3) : 9-15.

Boyd CE. 2015. Water Quality An Introduction. Second Edition. Auburn : University Auburn.

Craig S, LA. Helfrich. 2017. Understanding Fish Nutrition, Feeds and Feeding. Virginia State University, Virginia. Hlm; 4-5.

Christwardana M, Hadiyanto N. 2013. Review: Spirulina platensis: potensinya sebagai bahan pangan fungsional. Jurnal Aplikasi Teknologi Pangan 2(1): 1 - 4.

Effendie MI. 1979. Metodologi Biologi Perikanan. Yogyakarta: Yayasan Pustaka Nusatama.

Fazil M, Adhar S, Ezraneti R. 2017. Efektivitas penggunaan ijuk jerami padi dan ampas tebu sebagai filter air pada pemeliharaan ikan mas koki (Carassius auratus). Acta Aquatica, Aquatic Science Journal 4(1): 37 43.

Fitiyana N, Subamia WI, Wahyudi S. 2013. Pertumbuhan dan performasi warna ikan mas koki (Carassius .sp) melalui pengkayaan pakan dengan kepala udang. Al-Kauniyah Jurnal Biologi 9(2):1-12.

Furuichi M. 1988. Dietary requirements. 21-78. In Fish nutrition and mariculture. $\mathrm{T}$ watanabe. (Editor). Kanazawa International Fisheries Center. Japan International Cooperation Center.

Hasan B. 2012. Pertumbuhan dan komposisi tubuh ikan baung(Mystus nemurus $\mathrm{C} . \mathrm{V})$ yang diberikan pakan dengan kandungan protein berbeda pada kolam mengalir. [Skripsi]. Pekanbaru: Universitas Riau.

Iskandar R, Elrifadah. 2015. Pertumbuhan dan efisiensi pakan ikan nila (Oreochromis niloticus) yang diberi 
pakan buatan berbasis kiambang. ZIRAA'AH 40(1):18- 24.

Isnawati N, Sidik R, Mahasri G. 2015. Potensi serbuk daun pepaya untuk menigkatkan efisiensi pemanfaatan pakan, rasio efisiensi protein dan laju pertumbuhan relatif pada budidaya ikan nila (Oreochromis niloticus). Jurnal Ilmiah Perikanan dan Kelautan 7(2): 121-124.

Koru E. 2012. Eart food Spirulina (Arthrospira): Production and quality standarts, food additive. Izmir: Fisheries Faculty, Ege University.

Linne RE, Suryanto A. Muskanofola RM. 2015. Tingkat kelayakan kualitas air untuk kegiatan perikanan di wilayah waduk pluit Jakarta Utara. Diponegoro Journal of Maquares Management of AquaticResources $4(1): 35-45$.

Lochmann RT, Phillips H. 1994. Dietary protein requirement of juvenile golden shiners (Notemigonus crysoleucas) and goldfish (Carassius auratus) in aquaria. Aquaculture. Amsterdam. 128(3-4): 277 - 285.

Marbun TP, Bakti D, Nurmatias. 2015. Pembenihan ikan mas koki (Carassius auratus) dengan menggunakan berbagai substrat. [Skripsi]. Medan: Universitas Sumatera Utara.
Mashudi. 2006. Ikan Mas Koki Untuk Kontes. Jakarta:CV. Citra Cipta Purwosari

Muarif. 2016. Karaktersistik suhu perairan di kolam budidaya perairan. Jurnal Mina Sains 2(2) : 96 - 101.

Mulyadi, Abraham M, Nuraini H. 2011. Pengaruh padat tebar terhadap pertumbuhan dan kelulushidupan ikan selais (Ompok hypophthalmus) pada keramba. Jurnal Perikanan dan Kelautan 16(1): 33 - 47.

Nur MMA. 2014. Potensi mikroalga sebagai sumber pangan fungsional di indonesia (overview). Jurnal Eksergi 11(2): $01-06$.

Putra AN. 2010. Kajian probiotik, prebiotik, dan sinbiotik utuk meningkatkan kinerja pertumbuha ikan nila (Oreochromis niloticus). [Tesis]. Bogor: Institut Pertanian Bogor.

Yudiarto S, Arief M, Agustono. 2012. Pengaruh penambahan atraktan yang berbeda dalam pakan pasta terhadap retensi protein, lemak dan energy benih ikan sidat (Anguilla bicolor) stadia elver. Jurnal Ilmiah Perikanan dan Kelautan 4(2): 135-140.

Zonneveld N, Huisman EA, Boon JH. 1991. Prinsip-prinsip budidaya ikan. Jakarta: Gramedia Pustaka Utama. 